\title{
Implemntasi Teori Belajar Konstruktivisme Vygotsky Pada Mata Pelajaran Pai Di SMA Sains Qur`An Yogyakata
}

\author{
Muhibbin \\ Universitas Islam Negeri (UIN) Sunan Kalijaga Yogyakarta \\ ibinmuhib96@gmail.com \\ M. Arif Hidayatullah \\ Universitas Islam Negeri (UIN) Sunan Kalijaga Yogyakarta \\ m.arifhidayullah@gmail.com
}

\begin{abstract}
This study aims to answer the question of how and the implementation of vygotsky constructivism learning theory in PAI subjects at the Qur an High School. The method used in this study is a qualitative research method, the instruments used by researchers in this study, are the researchers themselves and notebooks. Furthermore, the results of research on the implementation of constructivist learning theory in general can be said to be going well and in accordance with the steps of its application. In implementing constructivist learning models in general, PAI subjects in the Qur'an Science High School can run well and cannot be separated from several supporting factors such as the accuracy of teaching materials, methods, principals, teachers, and adequate infrastructure. In addition to supporting factors there are also several inhibiting factors in the constructivist learning model in general, namely the insufficient allocation of time and the lack of self-confidence of students at the beginning of the application of constructivist learning models. Efforts that can be made to overcome the inhibiting factors of constructivist learning models in general are teachers trying to form positive attitudes in students such as self-confidence and mutual respect besides sending teachers to attend training, work shops.
\end{abstract}

Keywords: Implementation, Vygotsky's Constructivism Theory, PAI Subjects

Abstrak: Penelitian ini bertujuan untuk menjawab pertanyaan tentang bagaimana dan implemntasi teori belajar konstruktivisme vygotsky pada mata pelajaran PAI di SMA Sains Qur`an. Metode yang digunakan dalam penelitian ini adalah metode penelitian kualitatif, instrumen yang

Belajea: Jurnal Pendidikan Islam Vol. 5, No 01, 2020; 11

p-ISSN 2548-3390; e-ISSN 2548-3404, DOI:10.29240/belajea.v5

available online at:http://journal.staincurup.ac.id/indek.php/belajea 
114 | Belajea: Jurnal Pendidikan Islam, Vol. 5, No. 01, 2020

digunakan peneliti pada penelitian ini, adalah peneliti sendiri dan buku catatan. Selanjutnya hasil penelitian tentang Implementasi teori belajar konstruktivistik secara umum sudah bisa dikatakan berjalan dengan baik dan telah sesuai langkah penerapanya. Dalam pengimplemntasian model pembelajaran konstruktivistik secara umum pada mata pelajaran PAI di SMA Sains Qur an dapat berjalan dengan baik serta tidak bisa terlepas dari beberapa faktor pendukung seperti ketepatan bahan ajar, metode, kepala sekolah, guru, dan sarana prasarana yang mencukupi. Selain factor pendukung juga ada beberapa faktor penghambat dalam model pembelajaran konstruktivistik secara umum yakni alokasi waktu yang kurang mencukupi serta kurangnya rasa percaya diri siswa pada awal penerapan model pembelajaran konstruktivistik. Upaya yang dapat dilakukan untuk mengatasi faktor penghambat dari model pembelajaran konstruktivistik secara umum adalah guru mencoba membentuk sikap positif pada peserta didik seperti rasa percaya diri dan saling menghormati selain itu mengirim guru-guru untuk mengikuti pelatihan, work shop.

Kata kunci: Implementasi, Teori Konstruktivisme Vygotsky, Mata Pelajaran PAI

\section{Pendahuluan}

Pendidikan merupakan suatu hal yang sangat penting dalam kehidupan manusia, karena melalui pendidikan tersebut manusia dapat menumbuh kembangkan potensi yang ada pada dirinya. Manusia dikatakan sebagai mahluk sosial karena memiliki kemampuan berinteraksi dengan lingkungannya baik lingkungan fisik, maupun lingkungan sosial. Maka dari pada itu, diperlukan cara ataupun metode yang sesuai serta tidak hanya menjadikan proses belajar mengajar menarik akantapi dapat memberikan kesempatan bagi peserta didik untuk menuangkan kreatifitasnya dan selalu ikut aktif selama kegiatan belajar berlangsung.

Sebagai mana pendapat yang dikutip oleh Abdul Mujib dalam bukunya, Guru adalah orang yang memiliki tugas dan tanggungjawab jawab besar dalam perkembangan peserta didik, dengan cara mengembangkan seluruh potensi yang dimiliki oleh peserta didik, baik potensi kognitif, afektif, dan 
pisikomotorik. ${ }^{1}$ Selain itu guru bisa juga disebut sebagai agen pembelajaran. Untuk itu guru dituntut agar mampu merancang dan meciptakan suasana belajar mengajar yang nyaman dan menarik, tidak hanya itu guru juga diharapkan memilih metode yang sesuai dengan kondisi peserta didik.

Guru dituntut harus bisa menyesuaikan dengan perkembangan peserta didik. Seorang pendidik tidak bisa memindahkan pengetahuan yang dimiliki kepada siswanya, akan tetapi pendidik tersebut membimbing siswanya tersebut agar dapat membangun sendiri pengetahuannya selain itu seorang pendidik dituntut agar mampu memahami bagaimana jalan pikiran atau cara belajar siswanya. ${ }^{2}$ Artinya disini guru tidak lagi menganggap siswa sebagai objek pendidikan akan tetapi melihat siswa sebagai subjek pendidikan. Jika guru hanya memberikan informasi, dan mengharapkan siswa, mencatat, menghapal dan mengingat ini akan membuat siswa menjadi pasif akibatnya siswa tidak akan mampu mengembangkan pengetahuan yang dimilikinya.

Pada kenyataanya banyak guru ataupun dosen yang masih mengajar hanya dengan metode ceramah, dan mengharapkan siswa duduk diam, mendengar, mencatat dan menghafal. Dalam hal ini siswa juga kurang memperoleh perhatian dari aspek penerimaan pesan pelajaran dikarenakan pada dasarnya siswa mempunyai cara yang beragam dalam menerima ataupun merespon pelajaran yang diberikan. Mereka menganggap bahwa bahwa pandangan seperti ini adalah satu satunya jalan alternatif dalam proses pembelajaran yang dilakukan. Tentu saja hal ini kurang efektif terhadap kegiatan pembelajaran tersebut. Seharusnya guru memperhatiakan kesediaan, kemampuan, pertumbuhan, perbedaaan peserta didik, membangkitkan gairah peserta didik, merancang serta mengatur proses belajar yang baik, serta hubungan manusiawi dalam proses belajar mengajar. ${ }^{3}$ Kaitanya dengan permasalahan tersebut banyak sekali model-model pembelajaran yang dapat kita gunakan salah satunya adalah pembelajaran konstruktivistisme.

Konstruktivisme ini merupakan dasar berfikir (filosofi) pendekatan kontekstual, yakni pengetahuan yang dibentuk secara bertatahap, selanjutnya hasil tersebut diperluas melalui konteks yang sempit atau terbatas dan tidak

${ }^{1}$ Abdul Mujib, Jusuf Mudzakkir, Ilmu Pendidikan Islam, (Jakarta: Kencana, 2010 . Hlm. 87.

${ }^{2}$ Jumanta Handayana, Metodelogi Pengajaran, ( Jakarta: Bumi Aksara, 2016), Hlm. 45.

\footnotetext{
${ }^{3}$ Abdul Mujib, Jusuf Mudzakkir, Ilmu ...., Hlm. 93.
} 
116 | Belajea: Jurnal Pendidikan Islam, Vol. 5, No. 01, 2020

dengan langsung sekaligus. Pengetahuan bukan merupakan sejumblah fakta, ataupun konsep yang langsung bisa untuk diambil dan diingat. Akan tetapi disini manusia sendiri harus membangun pengetahuannya itu serta memberikan pemaknaan melalui pengalaman nyatanya. ${ }^{4}$ Namun dalam hal ini Vygotsky lebih menitik beratkan instraksi dari faktor-faktor interpersonal (social) kultural-historis dan individual sebagai kunci dari perkembangan manusia. $^{5}$

Adapun beberapa prinsip pembelajaran dengan pendekatan konstruktivisme ini tengah melahirkan bermacam model pembelajaran sehingga dari berbagai pandangan ini terdapat pandangan yang memiliki kesamaaan menganggap bahwa dalam belajar siswa merupakan pelaku aktif dalam proses belajar tersebut siswa membangun sendiri pengetahuan berdasarkan pengalamannya. ${ }^{6}$

Setiap sekolah ataupun perguruan tinggi memimpikan peseta didiknya atau lulusanya menjadi orang-orang yang berhasil dan sukses dimasa yang akan mendatang. Akan tetapi, begitu beratnya tanggung jawab harus diemban tersebut. Karena, pada kenyataan belum semua lulusan tersebut mampu menjadi lulusan yang diimpikan-impikan selama ini. Walaupun hal ini hanya baru saja berupa informasi yang belum jelas, namun hal tersebut membuat orang tua banyak mengeluh.

Peroblema yang seperti ini hampir dihadapi oleh semua sekolah yaitu bagaimana caranya untuk meciptakan metode atupun cara pola pendidikan yang sesuai untuk mengatasi hal tersebut. DI SMA Sains Qur`An telah mencoba melakukan upaya-upaya dalam pengembangan sistem pembelajaran khususnya pada mata pelajara PAI, yang salah satunya dengan mencoba menerapkan pendekatan konstruktivisme yang sesuai dengan karakteristik Pendidikan Agama Islam.

Esensi dari teori konstruktivisme adalah ide bahwa siswa harus menemukan dan mentransformasikan suatu sistem yang kompleks kesituasi lain dan apabila dikehendaki informasinya kompleks ke dalam keadaan dan Hlm. 88

${ }^{4}$ Saiful Sagala, Konsep Dan Makna Pembelajaran, (Bandung: Alfabeta, 2011),

${ }^{5}$ As Janah Verrawati, Implikasi Teori Konstruktivisme Vygotsky Dalam Pelaksanaan Model Pembelajaran Tematik Integratif Di SD, Jurnal Pendidikan Agama Islam.PDF, Hlm.3.

${ }^{6}$ Esa Wahyuni Baharudin, Teori Belajar Dan Pembelajaran, (Jogjakarta: Ar-Ruzz Media Group, 2007), Hlm 115. 
apabila hal ini dicapai informasi itu akan menjadi milik mereka sendiri. Dengan demikian proses pembelajaran harus dibentuk menjadi proses membangun pengetahuan bukan menerima begitu saja pengetahuan. ${ }^{7}$ Maksudnya disini teori konstruktivisme siswa sindirilah yang aktif menemukan dan merkonstrksi pengetahuanya sendiri dan guru hanya sebagai fasilitator.

Maka daripada itu, proses pembelajaran di SMA Sains Quran dirancang dan dikelola sedemikian rupa dengan tujuan agar mampu mendorong peserta didik mengorganisasi pengalamannya menjadi pengetahuan yang bermakna bermakna bagi dirinya. Jadi, pendekatan konstruktivistik ini sangat penting bagi peserta didik untuk membangun hibit berpikir, maka diperlukan keleluarsaan dan sikap belajar. Selanjutnya teori belajar ini harus mencerminkan bahwa siswa mempunyai kebebasan dalam belajar artinya disini siswa dapat menggunakan metode belajar belajar apasaja asalkan tujuan pembelajaran tersebut tetap dicapai.

\section{Pembahasan}

\section{A. Pembelajaran Konstruktivisme}

Teori belajar Konstruktivistikme memahami bahwa belajar merupakan sebuah proses membangun atau membentuk pengetahuan oleh siswa itu sendiri. Sebuah pengetahuan yang ada dalam memori seseorang yang memiliki pengetahuan tersebut tidak dapat dipindahkan begitu saja seperti memindahkan air dari wadah ke wadah lain begitu juga pengetahuan yang terdapat di dalam memori seorang guru kepada siswanya. ${ }^{8}$

Pembelajaran konstruktivisme adalah sebuah konsep pembelajaran yang didasarkan oleh sebuah pemahaman terhadap proses pembelajaran yang yang dilalui siswa adalah proses merekonstruksi sebuah pengetahuan serta pengalaman yang dilakukan dan dilalui siswa

\footnotetext{
${ }^{7}$ Saiful Sagala, Konsep...., Hlm.88.

${ }^{8}$ Jumanta Handayana, Metodelogi...., Hlm. 45.
} 
118 | Belajea: Jurnal Pendidikan Islam, Vol. 5, No. 01, 2020

tersebut. ' Dalam pembelajaran ini guru sebagai fasilitator dalam mengembangkan potensi yang ada pada peserta didik, disini siswalah yang berperan aktif membangun sendiri pengetahuannya melalui pemahamnya. Guru memberikan ruang kepada siswanya untuk berkreasi menuangkan ide-ide mereka sendiri dan secara sadar telah menggunakan strategi belajar mereka sendiri. Melalui pembelajaran konstruktivisme ini guru memberikan jalan kepada siswa ke pemahaman yang lebih tinggi melalui catatan-catatan yang telah mereka tulis menggunakan kata-kata mereka sendiri.

Melalui penjelasan di atas dapat diketahui bahwa belajar menurut konstruktivisme adalah kegiatan dimana peserta didik merekonstruksi pengetahuanya sendiri dengan cara mencari makna dari apa yang telah mereka pelajari dan melalui ide ataupun konsep yang telah mereka buat.

\section{B. Teori Belajar Konstruktivisme Vygotsky}

Lev Semenovich Vygotsky merupakan cendekia yang berasal dari Rusia, dia seorang ahli dalam bidang psikologi, filsafat, dan sastra. Filosofi Vygotsky yang sangat terkenal adalah mengenai manusia dan lingkungan, menurut Vygotsky 'manusia tidak seperti hewan yang hanya bereaksi terhadap lingkungan, manusia memiliki kapasitas untuk mengubah lingkungan sesuai keperluan mereka' (Schunk, 2012 : 338). Pemikiran filosofis Vygotsky mengenai manusia kemudian menjadi pelopor lahirnya teori konstruktivisme sosial yang artinya membangun kognitif anak melalui interaksi sosial. Vygotsky sangat tertarik mengupas esensi dari serangkaian aktivitas bermakna di lingkungan social-kultural dalam memperngaruhi konstruksi kognitif seorang anak. Maka dari itu pemikiran vygotsky sering disebut sebagai perspektif sosiokultural. ${ }^{10}$

Vygotsky mengemukakan pentingnya faktor-faktor social dalam belajar. Karena selama kegiatan belajar terdapat saling pengaruh antara bahasa dan tindakan dalam kondisi social. Dengan mengemukakan

${ }^{9}$ Mangun Wardoyo Sigit, Pembelajaran Konstrutivisme Teori Dan Aplikas Pembelajaran Dalam Pembentukan Karakter, (Bandung: Alfabeta, 2013), Hal. 4

${ }^{10}$ Yayu Tresna Suci, Menelaah Teori Vygotsky Dan Interdepedensi Sosial Sebagai Landasan Teori Dalam Pelaksanaan Pembelajaran Kooperatif Di Sekolah Dasar, Jurnal Kajian Penelitan Pendidikan Dan Pembelajaran Vol.3, No.1 (Oktober 2018), PDF, Hlm. 232. 
bahwa belajar itu harus berlangsung dalam kondisi social, terlihat betul bahwa dalam belajar konstruktif. Maka hal ini menjadi para peneliti konstruktif, mereka di kenal dengan nama konstruktivis social. ${ }^{11}$ Menurut Vygotsky, dasar fungsi mental manusia dibentuk secara alami dan dalam menumbuhkembangkan fungsi mental tersebut, maka manusia membutuhkan peranserta masyarakat dan budaya. Selanjutnya terkait dengan konsep dalam teori konstruktivisme Lev Vygotsky, Ormrod menjelaskan, bahwa Vygotsky berpendapat ada beberapa hal penting berkait dengan teorinya tersebut:

a. Terdapat jalinan hubungan antara anak dan orang dewasa baik secara formal ataupun informal yang akan memberikan pemahaman terhadap anak mengenai cara mereka berkembang.

b. Semua budaya mempunyai arti pada upaya peningkatkan ranah kognitif pada anak, makna budaya terhadap anak disisni memiliki tujuan untuk membimbing anak menjalani kehidupannya secara produktif dan efisien.

c. Berdasarkan pendapat Vygotsky perkembangan kognitif anak sangat tergantung pada bagaimana kemampuanya dalam menguasai bahasa.

d. Proses perkembngan mental secara sempurna terjadi ketika anak telah melakukan aktifitas sosial, kemudian secara perlahan akan mengalami pendalaman pada kognitif seorang anak bisa digunakan secara bebas.

e. Berdasarkan pendapat Vygotsky bahwa proses berfikir yang sempurna sangat bergantung pada bagaimana anak melakukan hubungan sosial. Seperti halnya berdiskusi membahasa masalah ataupun fenomena, bersama orang-orang yang lebih dewasa dan memiliki pengetahuan lebih darinya.

f. Seorang anak memiliki kemampuan mengerjakan tugas secara sempurna apabila tugas yang diberikan itu sifatnya menantang maka hal itu akan memberikan dorongan pererkembangan kognitif seorang anak dengan optimal. ${ }^{12}$

\footnotetext{
${ }^{11}$ Ratna Wilis Dahar, Teori-Teori Belajar Dan Pembelajaran, (Tampa Tempat Terbit: Erlangga, 2011), Hlm. 152

${ }^{12}$ As Janah Verrawati, Implikasi Teori Konstruktivisme Vygotsky...,Hlm.3-4
} 
120 | Belajea: Jurnal Pendidikan Islam, Vol. 5, No. 01, 2020

Ada dua prinsip yang perlu diturunkan dari teori konstruktivisme Vygotsky diantaranya: 1) Bahasa memiliki fungsi yang sangat penting dalam proses komunikasi sosial yang diawali dengan proses mengindra terhadap symbol atau tanda. 2) Zona of proximal development, yakni seorang pendidik merupakan mediator yang mempunyai peranan untuk membimbing siswanya mengkontruksi pengetahuannya.

Vygotsky menyebutkan bahwa belajar kontruktivisme ini adalah pengetahuan yang memiliki tingkatan atau jenjang yang disebut dengan Scaffolding. Scaffolding memiliki arti pemberikan bantuan terhadap seorang individu selama melewati tahap awal pembelajaran pada ahirnya bantuan tersebut akan dikurangi. Kemudian nantinya anak tersebut akan diberikan kesempatan untuk mengembanttanggung jawab yang besar tersebut sesudah anak tersebut memiliki kemampuan sendiri. Adapun bantuan yang diberikan ketika pembelajaran berlangsung bisa berupa pemberian contoh, arahan, peringatan, sehingga siswa tersebut dapat mentelesaikan suatu permasalahan secara mandiri.

Vygotsky menyebutkan bahwa ada tiga tingkat kemampuan yang dicapai oleh siswa dalam upaya menyelesaikan masalahan yang dihadapinya, yaitu: 1. keberhasilan yang dicapai secara mandiri, 2. Keberhasilan yang dicapai siswa melalui bantuan, 3. Kegagalan siswa dalam meraih keberhasilan.

Scaffolding merupakan usaha seorang guru dalam membimbing siswa untuk keberhasilan. Bimbingan guru terhadap siswa sangat diperlukan dengan tujuan mencapai tingkat tinggi sehingga menjadi sempurna. Teori konstruktivisme Vygotsky memiliki pandangan bahwa pengetahuan dibangun dengan cara kolaborasi antara inividual dengan individu lainya kemudian menyesesuaikannya sesuai keadannya. Proses pengkondisiaan tersebut dapat diarahkan dengan cara melakukann penyesuaian intelektual dengan kondisi sosial budaya. Proses adaptasi ini sama dengan membangun pengetahuan individu, yaitu dengan melewati proses yang disebut regulasi diri secara internal. Jadi dalam hal ini, para 
konstruktivis Vygotsky ini lebih menekankan pada cara bertukar pikiran/serring antara individu yang satu dengan yang lain. ${ }^{13}$

Pembelajaran PAI

Pembelajaran PAI merupakan proses pembentukan pengetahuan, sikap dan keterampilan oleh peserta didik melalui kinerja kognitifnya yang berbasis fakta dan fenomena sosial keagamaan yang kontekstual. Pembelajaran mengandung tiga karateristik utama yaitu: (a) proses pembelajaran melibatkan proses mental secara maksimal yang menghendaki aktivitas peserta didik untuk berpikir, (b) pembelajaran diarahkan untuk memperbaiki dan meningkatkan kemampuan berpikir tingkat tinggi yang pada gilirannya kegiatan berpikir itu dapat membantu peserta didik untuk memeroleh pengetahuan yang mereka konstruksi sendiri, dan (c) pembelajaran PAI yang berupa ajaran-ajaran, prinsipprinsip dan dogma-dogma agama Islam itu diupayakan sekontekstual mungkin disesuaikan dengan fakta, fenomena sosial keagamaan dan perkembangan Ilmu Pengetahuan dan teknologi (IPTEK), sehingga pemahaman agama tidak tekstualis/kaku namun fleksibel dan tetap dalam koridor metodologi yang valid. Dengan demikian PAI memiliki makna bagi kehidupan peserta didik. ${ }^{14}$ Oleh karena itu, pembelajaran PAI mengarusutamakan pada pembentukan sikap dan perilaku beragama melalui kontekstualisasi ajaran agama, pembiasaan, pembudayaan, dan keteladanan semua warga madrasah. Iklim akademis-religius perlu diciptakan sedemikian rupa sehingga budaya madrasah menjadi wahana bagi persemaian faham keagamaan yang moderat, internalisasi akhlak mulia, budaya anti korupsi dan model kehidupan beragama, berbangsa dan bernegara yang baik bagi masyarakat. Hubungan guru dengan peserta didik dalam proses

${ }^{13}$ Rizky Wahyuning Esa, Penerapan Teori Belajar Konstruktivisme Pada Pembelajaran Pendidikan Agama Islam Berbantuan Media Video Kelas VII Di SMPN 87 Jakarta, Jurusan Pendidikan Agama Islam Fakultas Ilmu Tarbiyah Dan Keguruan Universitas Islam Negeri Syarif Hidayatullah Jakarta 2017. PDF, Hlm. 18-19

${ }^{14}$ Keputusan Menteri Agama Republik Indonesia Nomor 183 Tahun 2019 Tentang Kurikulum Pendidikan Agama Islam Dan Bahasa Arab Pada Madrasah, Pdf, Hlm.49 
122 | Belajea: Jurnal Pendidikan Islam, Vol. 5, No. 01, 2020

pembelajaran dibangun dengan ikatan kasih sayang dan sating membantu bekerja sama untuk menggapai ridlo Allah Swt ${ }^{15}$

\section{Metode Penelitian}

Metode yang digunakan dalam penelitian ini adalah metode penelitian kualitatif. Penelitian kulitatif merupakan penelitian yang digunakan untuk meneliti kondisi objek yang alamiah. ${ }^{16}$ Instrumen yang digunakan peneliti pada penelitian ini, adalah peneliti sendiri dan buku catatan. Sedangkan tehnik pengumpulan data yang di gunakan dalam penelitian ini adalah observasi, wawancara dan dokumentasi. setelah data terkumpul kemudian selanjutnya dianalisis dan disimpulkan. Observasi digunakan untuk memperoleh data terkait tentang proses implemetasi teori belajar konstruktifisme Vigotski pada mete pelajaran PAI, kemudian wawancara diuntuk memperoleh data terkait tentang factor pendukung dan penhambat implemetasi teori belajar konstruktifisme Vigotsky di SMA Sains Quran Yogyakarta dan upaya yang dilakukan dalam mengatasi peramsalahan yang dihadapi. Sedangkan dokumentasi digunakan untuk memperoleh data-data yang dibutuhkan peneliti dalam bentuk dokumen ataupun catatan.

\section{Hasil Penelitian}

a. Implementasi Teori Kontruktivistik Vygotski Pada Mata Pelajaran PAI di SMA Sains Qur`an

Guru memulai pembelajaran dengan salam, menyapa dan berdoa, selanjutnya guru mengecek kehadiran siswa untuk mengetahui siap siswa yang hadir. Dalam kegiatan awal pembelajaran dibutuhkan waktu 15 menit untuk mengkondisikan siswa agar siap secara fisik dan mental mengikuti proses pembelajaran. Materi yang diberikan pada mata pelajaran PAI di kelas $\mathrm{XI}$ adalah tentang Etos kerja. Metode yang digunakan guru adalah dengan

\footnotetext{
${ }^{15}$ Ibid., Hlm.50

${ }^{16}$ Sugiyono, Metode Penelitian Pendidikan Pendekan Kulitatif \& Kuantitatif, (Banadung: Alfabeta, 2011), Hlm.15
} 
diskusi kelompok. Langkah - langkah yang terdapat pada metode ini diantaranya :

1. Guru mengadakan apresepsi sebagai pendahuluan dengan memberikan motivasi agar peserta didik lebih bergairah dalam mengikuti kegiatan belajar. Dalam hal ini guru memutar video tentang etos kerja.

2. Guru membentuk kelompok-kelompok kecil.

3. Tiap siswa menulis pelajaran apa yang dapat diambil dari video tentang etos kerjater sebut.

4. Selanjutnya siswa mendiskusikan pendapat mereka tentangetos kerja.

5. Guru membimbing siswa untuk menulis rumusan hasil diskusi secara berkelompok tentang etos kerja.

6. Siswa mempresentasikan hasil diskusinya dengan kelompok lain.

7. Guru dan siswa merumuskan kesimpulan dari hasil diskusi. Setelah itu guru menutup pembelajaran dengan berdoa.

8. Guru memberikan evaluasi dengan mengerjakan soal yang ada dalam buku paket.$^{17}$

b. Faktor Pendukung dan Penghambat Implementasi Teori Kontruktivisme Vygotsky Pada Mata Pelajaran PAI di SMA Sains Qur`an

Semua metode atau pendekatan yang digunakan dalam kegitan pembelajaran tentunya mempunyai kelebihan dan kekurangan tersendiri. Begitu juga dalam pelaksanaan pembelajaran konstruktivistik yang pastinya terdapat faktor pendukung ataupun penghambat dalam menerapkan model pembelajaran konstruktivisme

1. Faktor pendukung

Berikut ini merupakan faktor pendukung dalam implmentasi pembelajaran konstruktivistik antara lain sebagai berikut :

a) Adanaya relevansi antara metode, materi dan media yang digunakan dalam pembelajaran

${ }^{17}$ RPP Mata Pelajaran Pendidikan Agama Islam 
124 | Belajea: Jurnal Pendidikan Islam, Vol. 5, No. 01, 2020

Berdasarkan hasil wawancara dengan ibu Rifqi yang telah di lakukan peneliti di sekolah bahwasanya, dalam menyampaikan materi atau bahan pelajaran perlu adanya kesesuaian antara metode yang dipakai dalam menerapkan model pembelajaran konstruktivistik secara umum, dan tidak menutup kemungkinan juga adanya penggunaan media penunjang seperti media video hal ini digunakan membantu siswa memahami materi yang dipelajari. Maka dari pada itu metode yang digunakan perlu memiliki kesesuaikan antara metode dengan materi pada saat pembelajaran berlangsung. misalkan pada materi PAI yang berkaitan dengan Fiqih tentang pengurusan jenazah, maka metode yang paling tepat digunakan disini adalah metode praktek, namun dalam hal ini kita tidak menggunakan metode lain seperti metode metode ceramah karena diperlukan untuk memberikan penjelaskan mengenai halhal yang harus dilakukan oleh siswa. Selanjutnya ada kemungkinkan diterapkanya juga metode diskusi, dikarnakan dari hasil praktek yang sudah dilakukan oleh siswa mebutuhkan diskusi memecahkan masalah yang hadapi. ${ }^{18}$

b) Kepala Sekolah

Kepala sekolah peran yang penting pada penerapan pendekatan konstruktivistik karena kepala sekolah sapat menjadi dorongan untuk para guru di sekolah tersebut yang nantinya akan member dampak positif terhadap peningkatkan mutu dan keprofesionalan guru dalam dalam melakukan tugasnya dalam kegiatan belajar mengajar. Adapun motivasi tersebut dalam bentuk sherring/diskusi. Motivasi disini berupa dukungan yang terus menerus diberikan oleh kepala sekolah melalui pengadaan sherring antara kepala sekolah dengan para guru di sekolah tersebut. Berdasarkan hasil wawancara dengan bapak Aqib Fatah Abdi, S.E selaku Kepala Sekolah SMA mengatakan bahwa:

"Untuk mengetahui problem yang dihadapi oleh guru, saya selalu mengadakan kegiatan sherring pada setiap bulan. Dari sana saya

${ }^{18}$ Wawancara, 31 Oktober 2019 
bisa mengetahui apakah ada kesulitan-kesulitan yang dihadapi para guru ketika mengajar? Apa faktor yang menghambatnya? Bagaimana cara penyelesaiannya? Tidak hanya kepala sekolah saja yang memberi saran atau jalan keluar untuk mengatasi maslah yang dihadapi, selain itu guru yang lain juga bisa sherring pengalaman mereka. Sehingga saya ataupun para guru bisa menambah ilmu." 19

c) Letak Lembaga yang Strategis

Berdasarkan observasi yang sudah dilakukan oleh peneliti mengenai lokasi yang SMA Sains Qur’an peneliti memberiakan kesimpulan berada pada posisis yang sangat strategis dan kondusif sehingga sehingga membuat proses belajar mengajar dapat berjalan dengan baik. Selain itu SMA Sains Qur`an berada agak jauh dari jalan raya sehingga tidak terganggu oleh suara bising dari kendaraan yang sedang melewati jalan tersebut selain itu lokasi SMA Sains Qur`an dapat ditempuh dengan cara berjalan kaki atau dengan sepeda. ${ }^{20}$

2. Faktor penghambat

Dalam penerapan model pembelajaran konstruktivistik, tidak selalu berjalan dengan baik tentunya pasti selalu ada hambatan yang dihadapi. Adapun beberapa masalah yang di hadapi antaralain sebagai beriku :

1. Siswa kurang percaya diri

Poin penting yang menentukan keberhasilan seorang guru dalam menerapkan model pembelajaran konstruktivistik adalah pada siswa kepercaya diri tersebut akan menetukan apakah pembelajaran tersebut bisa berjalan atau tidak. Di SMA Sains Quran, pada awal menerapakan model pembelajaran tersebut siswa masih kurang percaya diri sehingga perlu adanya kesabaran

\footnotetext{
${ }^{19}$ Wawancara, 31 Oktober, 2019

${ }^{20}$ Observasi, 31 Oktober, 2019
} 
126 | Belajea: Jurnal Pendidikan Islam, Vol. 5, No. 01, 2020

guru dalam membimbing dan mengarakan siswanya. Hal ini sedikit dibahas oleh ibu, Rifqi S.Pd. ketika diwawancarai:

"Ketika menerapkan model pembelajaran konstruktivistik itu bisa dikatakan susah-susah gampang, karena pada saat awal siswa belum terbiasa dengan model pembelajaran tersebut, maka perlu ada waktu untuk beradaptasi dengan hal-hal yang baru oleh karena itu diperlukan kesabaran dalam mengahadapi hal seperti ini." ${ }^{21}$

Berdasarkan wawancara tersebut, maka penulis dapat memberikan kesimpulan, bahwa permaslahan yang dihadapi menerapkan model pembelajaran konstruktivisme di SMA Sians Qur'an adalah ketika pada awal penerapan metode/model pembelajaran baru, siswa belum terbiasa sehingga ini meyebapkan siswa merasa canggung dalam mengemukan pendapatnya.

2. Kemempuan memenjmen waktu

Berdasakan hasil observasi yang dilakukan oleh peneliti, bahwa dalam kegiatan pembelajaran menggunakan pendekatan konstruktivistik membutuhkan waktu yang tidak sedikit. Adapun waktu yang tersedia untuk menyapaikan bahan pelajaran dalam satu jam pelajaran adalah 45 menit, oleh karena itu guru telah menyaiapkan jauh jauh hari materi, metode ataupun media pendukung yang akan digunakan dalam kegiatan pembelajaran yang akan dilakukan seperti hanya peta konsep, gambar, video, dll.

c. Upaya Yang Dapat Dilakukan Untuk Mengatasi Masalah Dalam Menerapkan Teori Konstruktivistik Vygotsky

Adapun beberapa upaya yang dilakukan untuk mengatasi problem dalam menerapkan teori belajar konstruktivistik Vygotsky yaitu:

1. Mengikuti pelatihan-pelatiahan atau work shop.

Mengingat tugas dan tanggungjawab menjadi seorang pendidik semakin hari semakin berat. Maka penting sekali seorang

${ }^{21}$ Wawancara, 31 Oktober 2019 
guru selalu meningkatkan kompetensinya agar tidak ketinggalan informasi. Maka daripada itu SMA Sains Qur an banyak mencoba upaya-upaya yang bertujuan untuk kualitas gurunya sepeti mengikuti pelatihan-pelatihan, work shop dan lain sebaginya yang berkaitan dengan peningkatan kualitas guru. sesuai dengan wawancara kepada bapak Aqib Fatah Abdi, S.E selaku kepala SMA Sains Quran mengatakan bahwa:

"Untuk meningkatkan kualitas guru, saya memberikan undangan kepada para guru untuk mengikuti pelatihan, seminar, dll. Bahkan terkadang tanpa adanya undangan dari sekolah, para disini mempunyai inisiatif sendiri untuk menghadiri pelatihan, seminar, atau apapun yang dapat meningkatkan mutu dan kualitas mengajarnya."22

2. Mengadakan diskusi/sherring dengan para guru

Berdasarkan hasil wawancara yang dilakukan oleh peneliti dengan Ibu Rifqi pada tanggal 31 oktober 2019 bahwa setiap satu bulan sekali dengan para guru mengadakan diskusi yang memiliki tujuan untuk mencari permasalahan dihadapi oleh para guru ketika melakukan kegiatan belajar mengajar ataupun lainya dan mencari solusi untuk menyelsaikan permasalahan tersebut.

3. Memberikan motivasi/dorongan belajar kepada siswa

Motivasi dalam belajar adalah sesuatu yang sangat penting untuk mendorong siswa dalam mencapai prestasi belajar. Maka dari pada itu, guru memiliki tugas dan tanggung jawab untuk selalu memotivasi siswanya agar semangat dalam belajar. Berhubungan dengan hal ini, Ibu Rifqi yang merupakan guru mata pelajaran PAI telah melakuan upaya untuk meningkatkan motivasi belajar siswa, beliau mengungkapkan:

"Hal-hal yang sering kali tidak terduga terjadi dalam proses pembelajaran, untuk mengatasi permaslahan tersebut diperlukan kesabaran dan keuletan dalam membimbing agar mereka tetap fokus kembali pada apa yang mereka pelajari. Akan tetepi hal ini belum

${ }^{22}$ Wawancara, 1 November 2019 
128 | Belajea: Jurnal Pendidikan Islam, Vol. 5, No. 01, 2020

cukup, karena kesuksesan sebuah pembelajaran terletak pada bagaimana seorang guru dalam memberikan motivasi atau dorongan kepada siswa agar mereka lebih besemangat lagi dalam belajar. Untuk memotivasi siswa diperlukan metode yang beragam, menciptakan suasana yang kondusif, memberikan tugas yang sesuai dengan porsi siswa, memberikan masukan kepada siswa, danhal yang tidak kalah palingnya adalah tidak boleh membanding kemampuan siswa yang satu dengan yang lain karena itu akan membuat mereka sakit hati.",23

4. Sarana dan prasarana yang mendukung proses pembelajaran.

Sarana dan prasarana adalah komponen yang sangat penting dalam kegiatan belajar dan mengajar. Maka berbagai upaya terus menerus dilakukan oleh pihak sekolah tersebut guna meningkatkan kualitas pendidikannya seperti melakuakan perbenahan ataupun penambah sarana dan prasarana di sekolah. Sesuai dengan hasill wawancara dengan bapak Wakhid Nur Salim, S.Pd mengatakan :

"Mengenai penambahan jumlah ataupun pembenahan sarana dan prasarana, pasti kami lakukan disetiap tahun, namun semua itu dilakukan secara bertahap. Mengingat besarnya dana yang harus dikeluarkan." 24

\footnotetext{
${ }^{23}$ Wawancara, 31 Oktober 2019

${ }^{24}$ Wawancara, 7 November 2019
} 


\section{Penutup}

Berdasarkan hasil analisis data yang telah didapatkan peneliti, maka dapat disimpulan bahwa :

1. Implementasi teori belajar konstruktivistik secara umum pada mata pelajaran PAI di SMA Sains Qur`an sudah terlaksana dengan baik sesuai dengan prosedur dalam pembelajaran yang sudah ada.

2. Penerpan pembelajaran konstruktivistik secara umum pada mata pelajaran PAI di SMA Sains Qur`an berjalan dengan baik karena faktor pendukung, seperti kesesuaian antara bahan ajar dengan metode digunakan, dukungan dari kepala sekolah, guru, serta sarana prasarana yang mendukung.

3. Selain adanya factor pendukung dalam kegiatan pembelajaran, ada juga faktor penghambat dalam penerapan dari model pembelajaran konstruktivistik secara umum pada mata pelajaran PAI di SMA Sains Quran yakni factor waktu, kurangnya rasa percaya diri siswa pada awal penerapan model pembelajaran konstruktivistik dikaranakan perlu adanya peyesuaian yang dilakukan oleh siswa.

4. Solusi yang dapat dilakukan untuk mengatasi hambatan yang dihadapi dari pembelajaran konstruktivistik secara umum adalah guru membantu menanamkan sikap percaya diri dan saling menghormati pada diri siswa. Melakukan kegiatan pelatihan-pelatian, work shop tertentu yang dapat meningkatkan mutu dan kualitas mengajar guru. Guru dan kepala sekolah selalu mengadakan diskusi untuk membicarakan tentang kegiatan belajar mengajar yang telah dilakukan dalam satukali satu bulan. Serta melakukan penambahan ataupun pembenahan terhadap sarana dan prasarana yang dapat menunjang pembelajaran. 
130 | Belajea: Jurnal Pendidikan Islam, Vol. 5, No. 01, 2020

\section{Bibliografy}

Abdul Mujib, Jusuf Mudzakkir, Ilmu Pendidikan Islam, Jakarta: Kencana, 2010.

As Janah Verrawati, Implikasi Teori Konstruktivisme Vygotsky Dalam Pelaksanaan Model Pembelajaran Tematik Integratif Di SD, Jurnal Pendidikan Agama Islam.PDF.

Esa wahyuni Baharudin, Teori Belajar dan Pembelajaran, Jogjakarta: Ar-Ruzz Media Group, 2007.

Jumanta Handayana, Metodelogi Pengajaran, Jakarta: Bumi Aksara, 2016.

Keputusan Menteri Agama Republik Indonesia Nomor 183 Tahun 2019

Tentang Kurikulum Pendidikan Agama Islam Dan Bahasa Arab Pada Madrasah, Pdf.

Mangun Wardoyo Sigit, Pembelajaran Konstrutivisme Teori dan Aplikas Pembelajaran dalam Pembentukan Karakter, Bandung: Alfabeta, 2013.

Ratna Wilis Dahar, Teori-Teori Belajar dan Pembelajaran, tampa tempat terbit: Erlangga, 2011.

Rizky Wahyuning Esa, Penerapan Teori Belajar Konstruktivisme Pada Pembelajaran Pendidikan Agama Islam Berbantuan Media Video Kelas VII Di SMPN 87 Jakarta, Jurusan Pendidikan Agama Islam Fakultas Ilmu Tarbiyah Dan Keguruan Universitas Islam Negeri Syarif Hidayatullah Jakarta 2017. PDF

Saiful Sagala, Konsep dan Makna Pembelajaran, Bandung: Alfabeta, 2011.

Yayu Tresna Suci, Menelaah Teori Vygotsky Dan Interdepedensi Sosial Sebagai Landasan Teori Dalam Pelaksanaan Pembelajaran Kooperatif Di Sekolah Dasar, Jurnal Kajian Penelitan Pendidikan dan Pembelajaran Vol.3, No.1 (Oktober 2018), PDF.

Sugiyono, Metode Penelitian Pendidikan Pendekan Kulitatif \& Kuantitatif, Banadung: Alfabeta, 2011, 